\title{
4 Citizen preferences for co-investing in renewable energy
}

\author{
An empirical exploration of the \\ "community-as-investor" acceptance \\ of renewables' innovation
}

\author{
Cristian Pons-Seres de Brauwer and \\ Jed J. Cohen
}

\section{Introduction}

The "Clean Energy for All Europeans" (CEP) legislative package represents the legal framework to guide the European Union (EU) in decarbonising its energy system by mid-century. As part of its governance mechanism, EU Member States (MSs) have been tasked to design and deliver National Energy and Climate Plans (NECPs) in order to meet increasingly ambitious climate and energy targets by 2030. An important insight guiding NECP design ought to acknowledge that the disruptive changes required for a timely implementation of national decarbonisation strategies cannot be fully realised by an exclusive reliance on renewable energy (RE) technological innovations, as their mass-scale diffusion and systemic adoption entail important shifts in the ways we currently organise, govern and consume both energy supply and its end-use services (Smith, 2016; Hoppe and de Vries, 2018; Hoppe, Butenko and Heldeweg, 2018). In other words, the diffusion of renewables' innovation is inevitably subordinated to, and determined by, the extent in which they are progressively adopted by end-users across society - itself a function of the level of support (or contestation) expressed by different stakeholder groups across society.

As such, both the extent and pace of RE technology uptake will itself be determined by the relative legitimacy that local communities (end-users, residents, municipalities), market actors (developers and operators, investors, consumers), government authorities (policymakers, regulatory agencies) and the broader public delegate to its process of deployment (open and participatory vs. closed and private), the allocation of burdens and benefits (concentrated vs. distributed) and for its ease of use (seamless vs. faulty), among other considerations (Walker and Devine-Wright, 2008; Upham, Oltra and Boso, 2015; Wolsink, 2018). Success in RE innovation diffusion may therefore be better understood and addressed as a matter of "social acceptance" (Wüstenhagen, Wolsink and Bürer, 2007).

Importantly, due to its decentralised nature and bottom-up configuration, addressing acceptance challenges around RE infrastructure deployment inevitably 
requires "new ways of collaboration, decision-making, and of mobilising society" (Hoppe and de Vries, 2018, p. 2). Citizen-driven forms of RE generation locally embedded around participatory practices offers a promising vehicle through which to operationalise such changes.

\section{Research aim and objectives}

In order to catalyse citizen involvement in RE generation and obtain conditional NECP approval, MSs must transpose EU-CEP legislation ${ }^{1}$ concerning the rights and responsibilities of citizen-driven forms of RE generation into national enabling frameworks by June 2021 (Lowitzsch, Hoicka and van Tulder, 2020). However, national policy makers will most likely remain handicapped in their legislative efforts without an empirically validated informational source base guiding responsive policies to broaden citizen participation in energy decarbonisation efforts.

Limited understanding of the various characteristics shaping citizen participation in different RE initiatives may in turn result in deficient information flows that can potentially lead to misguided or insufficient RE investment decisions, as well as to regressive RE policies hindering (rather than supporting) citizen-financed RE developments. This might be particularly true for some BSR countries, where citizen investment preferences for co-financing communitydriven forms of RE generation have seldom been explored. ${ }^{2}$ The study reported in this chapter aims to address this information deficit through an analytical examination of different factors influencing citizen interest and participation in collective investment schemes for different RE project configurations throughout the BSR.

In order to do so, we use data from an international discrete choice experiment (DCE) survey conducted across every BSR country: Germany, Poland, Lithuania, Latvia, Estonia, Finland, Sweden, Norway and Denmark. Respondents were presented with different investment options to co-finance RE generation schemes. Through multinomial logistic regressions conducted on the survey data, we draw inference on the relative influence that different national socio-economic trends, energy cultures and demographic factors have in shaping citizen financial participation on different $R E$ investment schemes and derive empirically validated insights on citizen-centric RE policy support as a key constitutive pillar of NECP design.

We structure the chapter as follows: first, we conceptualise community renewable energy through a socio-technical lens and introduce insights from the social acceptance literature to enrich our conceptualisation. With this novel combination, we add to existing acknowledgements of citizens' salience for the realisation of sustainable energy transitions beyond their traditional "end-user" role (Göpel, 2016; Schot, Kanger and Verbong, 2016; Ingold, Stadelmann-Steffen and Kammermann, 2019). Also, we attempt to refine the social acceptance framework forwarded by Wolsink (2018) by exploring the conceptual space resulting from the overlap of the community and market acceptance dimensions of 
renewables' innovation - we call this the "community-as-investor" acceptance of renewables' innovation.

Secondly, we introduce the DCE survey as our main data collection tool, describe the development of our sampling and analytical methodologies and outline the steps taken throughout the data gathering process. We follow with a descriptive disclosure of our analytical outputs and present the results stemming from our regression analysis.

We then reflect on the policy implications stemming from our results and discuss the impact that the EU's latest shift on RE support policy - namely from a feed-in-tariff (FiT) system to a competitive tendering scheme in the form of auctions - has for incentivising citizen-led finance for CRE across the BSR. We specifically narrow in on the Danish and German experiences - two of the most prominent countries with long-standing traditions on cooperative association (Danielsen, 1995; Jørgensen, 1995; Kemp, Rip and Schot, 2001; Debor, 2018) to illustrate the challenges that such a policy shift has brought in terms of hindering a more actor-diverse RE development pathway in both countries.

\section{Theoretical considerations}

\section{Towards a socio-technical understanding of community renewable energy}

Citizen involvement in RE generation schemes has been the object of ample enquiry, capturing the attention of both policy and practice actors including project developers, asset operators, policy makers, local municipalities, residents, etc. (Creamer et al., 2019; Seyfang, Park and Smith, 2013). Due to its manifold attributes, diverse stakeholder dynamics and multiple project designs and legal configurations, citizen-driven or community-based RE has been subject to countless interpretations and multiple definitions, challenging integrative efforts to reach a broadly accepted definition and resulting in cautionary calls against single, all-encompassing definitions (Brummer, 2018; Hicks and Ison, 2018).

In that respect, "community renewable energy" (CRE) may be more safely approached as an umbrella term encompassing various different "innovative configurations for sustainability" operationalised through different organisational forms and/or collective investment vehicles co-driven by environmental and social goals (Smith et al., 2015). These may refer to energy cooperatives, municipality-owned utilities, community development trusts, consumer stock ownership plans or online crowdfunding platforms, to name a few (Hewitt et al., 2019; Lowitzsch, 2019; Bourcet and Bovari, 2020; Torabi Moghadam et al., 2020).

Mirroring this organisational versatility, the "community" condition attributed to the CRE concept has thus been appraised quite diversely, yet most commonly categorised either as a geographically delimited "community of place" with social interactions unfolding within a localised setting or as a "community of interest" extending participation beyond place-based contexts and facilitating interaction based on shared/common interests, such as geographically dispersed co-investors 
in a cooperative scheme (Walker, 2008, 2011). However, more often than not, different types of communities tend to coexist within one CRE scheme simultaneously (Bauwens and Devine-Wright, 2018). In that respect, the "community" quality of CRE is not necessarily ascribed in reference to the geographic scope of the scheme itself (e.g. localised, dispersed), but rather to its citizen-oriented participation and membership-based characteristics.

Cutting across this myriad of views and interpretations, however, are two key dimensions of "process" and "outcome" underlying different RE development configurations (Walker and Devine-Wright, 2008). While "process" refers to "who a project is developed by" and "outcome" to "who a project is developed for" (ibid., p. 409), both dimensions are anchored in reference to the extent through which different stakeholder groups relate to RE technology and its deployment - either through direct involvement or indirect affect. Importantly, these two dimensions highlight the prominence that social arrangements have in shaping RE technology deployment efforts irrespective of the scale, cost, efficiency, performance/functionality or any other defining techno-economic attribute of the innovation itself (Walker and Cass, 2007; Walker and Devine-Wright, 2008). Such an insight implies that RE diffusion is partly shaped by the socio-communal arrangement upholding it, with more open and collaborative arrangements (e.g. wind energy cooperative) conducive to potentially greater participation and hence socially accepted technology diffusion, than closed and private ones (e.g. private utility wind farm).

In that respect, the idea of "social innovation" - whereby social practices, institutions and networks are reconfigured to empower citizens in supporting novel solutions to address societal challenges - emerges as a highly relevant resource to guide, broaden and deepen citizen engagement through novel ways of generating, managing and consuming energy more sustainably (Cajaiba-Santana, 2014; MacCallum, 2016; Neumeier, 2017; Polman et al., 2017; Caiati, Marta and Quinti, 2019). It is this focus on citizen participation what positions CRE as a social innovation, as it effectively reconfigures citizens' energy consumption and production practices as a means to enact renewables' innovation diffusion processes (Hewitt et al., 2019).

However, it is precisely due to the RE technological innovation itself (i.e. its decentralised nature and enhanced modularity) that socially innovative ways of collaboration are enabled and more participatory socio-communal arrangements are made possible, in the first place (c.f. how many citizen-financed coal-fired or nuclear power cooperatives exist?). CRE might therefore be better understood as a "socio-technical" innovation for sustainability, whereby novel social arrangements (e.g. cooperative) organise around technological innovations (e.g. renewables, storage) moving across a bi-dimensional continuum of process (open $\leftrightarrow$ closed) and outcome (collective $\leftrightarrow$ private) (see Figure 4.1).

\section{The "community-as-investor" acceptance of renewables' innovation}

The socio-technical conceptualisation outlined above advances an understanding of CRE development as a societally embedded process of technological innovation diffusion (Smith, Voß and Grin, 2010; Scherrer, Plötz and Van Laerhoven, 


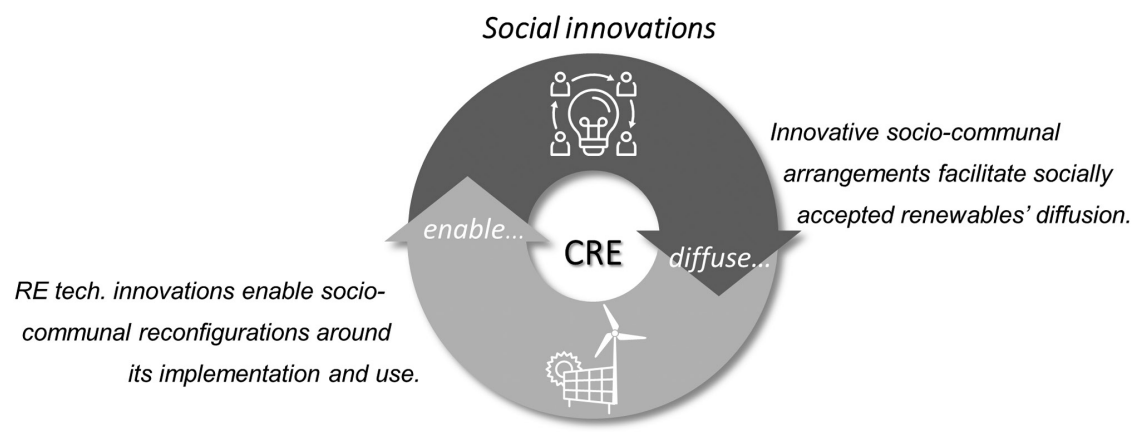

Technological innovations

Figure 4.1 Community renewable energy (CRE) as a socio-technically innovative approach for renewables' diffusion. Source: authors.

2020). Importantly, this positions CRE as a legitimation vehicle through which to disrupt the locked-in role of end-users as passive energy consumers, enabling individual citizens to join communities of place/interest to collectively finance a RE generation facility. In doing so, the subject of acceptance ${ }^{3}$ correspondingly shifts from traditional market incumbents (e.g. energy utilities, commercial project developers, capital fund managers, financial institutions, etc.) towards individual citizens in their newly acquired role as co-investors of socially innovative forms of RE generation.

Embedded in this new role, community-related concerns on e.g. procedural fairness, distributional justice, visual impacts, transparency, trust, place attachment etc., become entangled with investor-related considerations on e.g. market performance and revenue (un)certainty, tariff structures, fiscal obligations, regulatory risk, etc. As such, the community and market acceptance dimensions underlying both stakeholder groups progressively overlap under a hybrid "community-as-investor" acceptance dimension representative of the co-investor facet of individual citizens which emphasises the relations between the market, community and socio-political dimensions of RES developments (see Figure 4.2).

The community-as-investor acceptance is partly shaped by the information flows generated through the manifested preferences that individual citizens express for a myriad of differing characteristics cutting across the community, market and socio-political acceptance dimensions of CRE. For instance, more financially attractive co-investment schemes offering a higher return on investment or shorter holding periods may be better perceived than competing schemes offering lower returns or with longer holding times (Salm, Hille and Wüstenhagen, 2016; de Brauwer and Cohen, 2020). Additionally, socio-psychological motives such as an individual's particular (pro)environmental behaviour, place attachment, community identity or energy culture may shape the relative propensity to co-invest in any one particular CRE development (Bauwens, 2016; Cohen et al., 2019; Süsser, Döring and Ratter, 2017). Furthermore, certain national socio-economic 


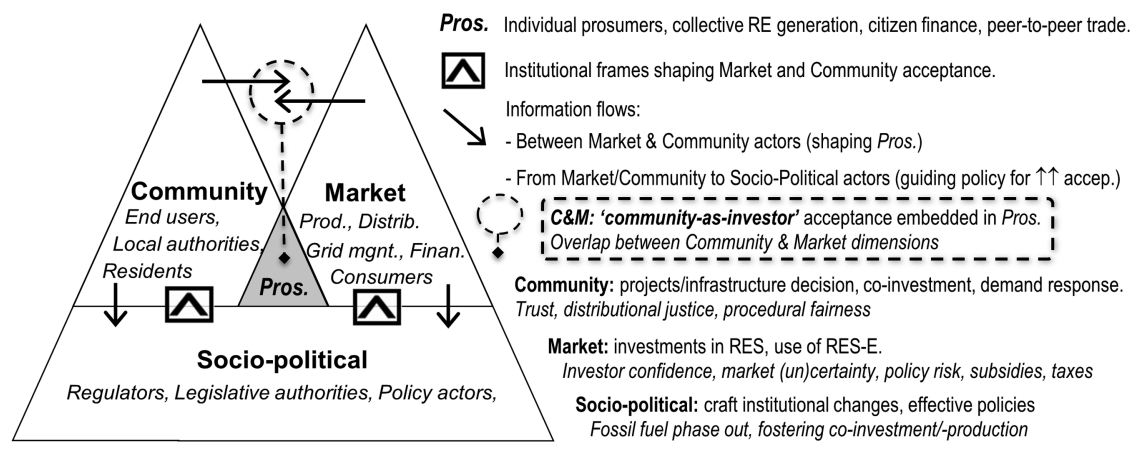

Figure 4.2 Multi-layered conceptualisation of the four dimensions of social acceptance of renewables' innovation - including the novel "community-as-investor" acceptance dimension derived from citizen co-investment on renewable energy generation. Source: conceptual illustration adapted from Wolsink (2018).

or demographic trends such as income/wealth distribution or incidence of energy poverty may also play a relevant role in nudging an individual's propensity to coinvest or not (Johansen and Emborg, 2018; Leiren et al., 2020).

Table 4.1 illustrates a selective categorisation of these various influencing factors for the BSR, under two main clusters of characteristics potentially shaping citizen preference formation for co-investing (or not) in CRE.

The relevance of the aforementioned factors in the table and other driving factors in shaping citizen involvement in renewables' innovation diffusion processes has been a recurrent object of enquiry across the acceptance literature. However, despite ample empirical work conducted in the context of socio-economic energy research, limited attention has been paid thus far to extend survey-based appraisals with experimental methodologies (Yildiz and Sagebiel, 2019). This may be particularly concerning given the increasing tendency towards evidence-based policy as a means to devise effective strategies to foster the diffusion of renewables' innovations, including socially innovative formats such as CRE (Sorrell, 2007).

The empirical enquiry outlined herein attempts to bridge this shortcoming through the development of an analytical procedure used on experimental data collected for every BSR country. The resulting analytical outputs may thus facilitate an empirically validated knowledge source base for calibrating more citizencentric NECP designs supporting community-anchored renewables' innovation diffusion processes across the BSR.

\section{Methods and data}

\section{Data collection: discrete choice experiment survey design and sampling methods}

The main data utilised for our analytical procedure was obtained from the responses reported to a discrete choice experiment (DCE) included as part of an 
Citizen preferences for co-investing 67

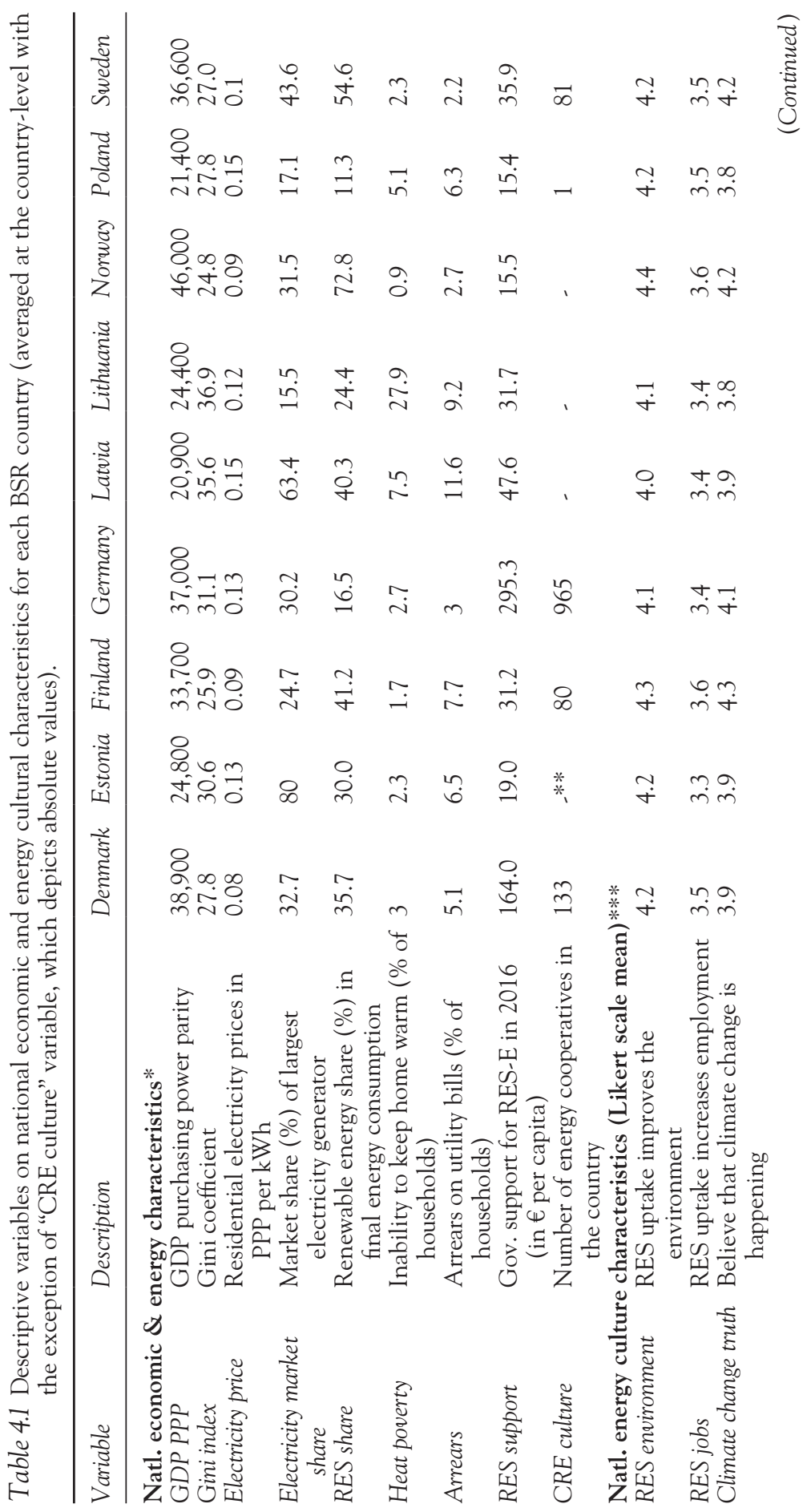


68 Pons-Seres de Brauwer and Cohen

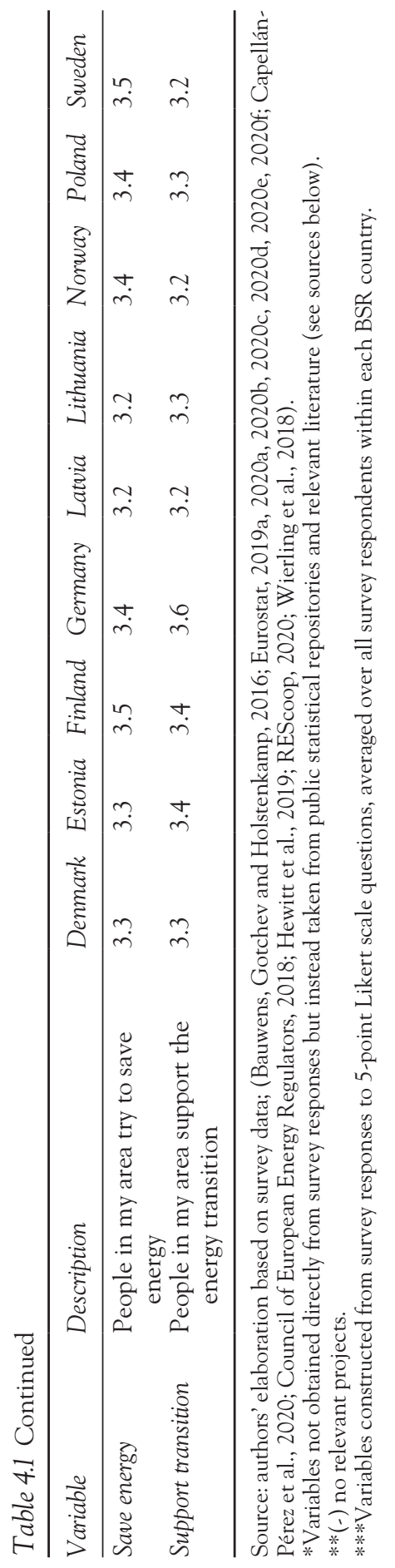


international survey conducted across every BSR country to identify different decision-driving factors on energy-related choices and behaviours. DCEs are a particularly well-suited data collection technique for our analytical purposes, as they enable us to estimate probabilistic models to investigate the relative influence of different socio-economic and demographic variables on individual preference and related choice dynamics (Yildiz and Sagebiel, 2019). As such, the purpose of the DCE section of the survey was to identify the respondents' levels of interest in participating in a community-based investment scheme to finance solar or wind energy projects consisting of different financial and operational characteristics and to infer the relative influence that national socio-economic trends, energy cultures and demographic characteristics have in shaping respondents' willingness to collectively finance CRE-based developments in their role of co-investor.

The DCE survey was distributed online by the market research firm Ipsos during 2018-2019. Country-specific panel samples consisted of around 600 respondents for each BSR country, with a total final sample of 5,425 respondents. Panel samples were drawn through a quota sampling procedure, with the requirement that the final samples were representative of each country's national population over the sociodemographic dimensions of age, gender and income $^{4}$ (see Table 4.2).

Table 4.2 Sociodemographic indicators included in the survey quota sampling process.

\begin{tabular}{|c|c|c|c|c|c|c|}
\hline \multirow[t]{3}{*}{ Country } & \multicolumn{6}{|l|}{ Indicator } \\
\hline & \multicolumn{2}{|l|}{ Age } & \multicolumn{2}{|l|}{ Gender } & \multicolumn{2}{|c|}{ Monthly income } \\
\hline & $\begin{array}{l}\text { Mean age } \\
\text { in sample }\end{array}$ & $\begin{array}{l}\text { Median } \\
\text { age of } \\
\text { population }\end{array}$ & $\begin{array}{l}\% \text { males in } \\
\text { sample }\end{array}$ & $\begin{array}{l}\% \text { males of } \\
\text { population* }\end{array}$ & Sample** & Population*** \\
\hline Denmark & 47.7 & 41.8 & $51 \%$ & $49 \%$ & $€ 2,093$ & $€ 2,449$ \\
\hline Estonia & 40.1 & 42.1 & $55 \%$ & $49 \%$ & $€ 805$ & $€ 782$ \\
\hline Finland & 42.7 & 42.7 & $52 \%$ & $49 \%$ & $€ 1,772$ & $€ 1,999$ \\
\hline Germany & 42.8 & 46.0 & $49 \%$ & $49 \%$ & $€ 1,653$ & $€ 1,827$ \\
\hline Latvia & 41.1 & 43.5 & $53 \%$ & $49 \%$ & $€ 600$ & $€ 551$ \\
\hline Lithuania & 43.0 & 43.8 & $55 \%$ & $49 \%$ & $€ 549$ & $€ 511$ \\
\hline Norway & 42.7 & 39.5 & $50 \%$ & $49 \%$ & 2,780 & $€ 3,206$ \\
\hline Poland & 42.8 & 40.7 & $50 \%$ & $49 \%$ & $€ 498$ & $€ 495$ \\
\hline Sweden & 42.7 & 40.8 & $51 \%$ & $51 \%$ & $€ 1,746$ & $€ 1,948$ \\
\hline BSR & 42.8 & 42.3 & $52 \%$ & $49 \%$ & $€ 1,388$ & $€ 1,530$ \\
\hline
\end{tabular}

Source: authors' elaboration based on Eurostat (2019b, 2019c, 2019d, 2019e).

* Obtained by taking each country's ratio of women per 100 men.

**Estimated mean value of equivalised monthly income in EUR; obtained from dividing the net household income per number of household members (based on quartile and 90th percentile cut-offs from survey respondents.)

***Estimated median value of equivalised monthly income in EUR (obtained by taking the 5th decile of each country's annual income and dividing it by 12 months). 


\section{Pons-Seres de Brauwer and Cohen}

DCE survey respondents were presented with eight different investment scenarios (choice tasks) in a random order, each one displaying a total of three different RE investment options (choice objects) to choose from. Two choice objects showcased a specific hypothetical investment opportunity displaying a unique combination of different investment and operational attributes related to a CRE development. A third "opt-out" option was included in each choice task where all attribute values were set to zero, provided in the case where a respondent had no interest to invest in any of the two hypothetical investment options disclosed in the choice task. Different investment and operational attributes were included in the investment opportunities/choice tasks, as well as the range of values randomly disclosed under those options (see Table 4.3).

Table 4.3 Investment and operational attributes, their descriptions and range of values.

\begin{tabular}{|c|c|c|}
\hline $\begin{array}{l}\text { Investment } \mathbb{E} \\
\text { operational attributes }\end{array}$ & Description & Values \\
\hline RE installation & $\begin{array}{l}\text { The type of renewable energy project } \\
\text { the respondent is investing in }\end{array}$ & $\begin{array}{l}\text { - Wind farm } \\
\text { - Solar park }\end{array}$ \\
\hline Capital requirement & $\begin{array}{l}\text { A randomly assigned, risk- } \\
\text { free investment amount the } \\
\text { respondent has to pay to join any } \\
\text { of the investment opportunities } \\
\text { being offered }\end{array}$ & $\begin{array}{l}\text { - } € 50 \\
\text { - } € 100 \\
\text { - } € 1,000 \\
\text { - } € 2,000 \\
\text { - } € 5,000\end{array}$ \\
\hline Profit rate & $\begin{array}{l}\text { A one-time lump sum payment to } \\
\text { the respondent at the conclusion } \\
\text { of the holding period, when the } \\
\text { RE project is finalised. Displayed } \\
\text { as a real rate of return on the } \\
\text { initial investment that already } \\
\text { accounts for inflation* }\end{array}$ & $\begin{array}{l}\cdot 0 \% \\
\cdot \quad 10 \% \\
\cdot \quad 20 \% \\
\text { - } 50 \%\end{array}$ \\
\hline Holding period & $\begin{array}{l}\text { The number of years elapsed } \\
\text { until the respondent's initial } \\
\text { investment and the profit } \\
\text { generated from it are both repaid }\end{array}$ & $\begin{array}{l}\text { - } 5 \text { years } \\
\text { - } 10 \text { years } \\
\text { - } 15 \text { years }\end{array}$ \\
\hline Visibility & $\begin{array}{l}\text { Whether or not the RE installation } \\
\text { is visible from the respondent's } \\
\text { home }\end{array}$ & $\begin{array}{l}\text { - Visible } \\
\text { - Not visible }\end{array}$ \\
\hline Administrator & $\begin{array}{l}\text { The legal entity overseeing the } \\
\text { respondent's investment and } \\
\text { in charge of building and } \\
\text { administering the RE installation }\end{array}$ & $\begin{array}{l}\text { - Community } \\
\text { organisation (e.g. energy } \\
\text { cooperative) } \\
\text { - Utility company } \\
\text { - Government entity (e.g. } \\
\text { municipality) }\end{array}$ \\
\hline
\end{tabular}

Source: authors.

*The CE defined "investments" as lump sum money transfers that are to be fully repaid at the conclusion of the holding period. This specificity allowed to disentangle the profit rate from the holding period and avoided the necessity to consider compounded interest, thereby simplifying the set of considerations that respondents had to account for when evaluating the profitability and, by extension, the preferred choice option. 
The eight different choice tasks were presented to each survey respondent from a randomly selected block in a random order. Respondents were then tasked with selecting one option for each of the eight different choice tasks, resulting in eight different choices per respondent and a final sample of 43,400 choice responses selected from 130,200 different choice objects (i.e. investment options) available (see Table 4.4).

Complementing the investment and operational attributes included in the DCE section of the survey, we further identify a set of proxy variables representative of national socio-economic trends, energy cultures and individual demographic factors potentially shaping survey participants' DCE survey responses and thus their willingness to collectively finance CRE-based developments in each BSR country. We split these into three different sets of variables (see Table 4.5).

The national economic, energy and energy culture variables in Table 4.5 contain nation-wide values for each BSR country, matched to respondent observations from respondents who live in the country. Due to collinearity, all national level variables disclosed in Table 4.1 cannot be included together in the choice model. However, the included variables still represent major national economic and energy indicators, including GDP per capita adjusted for purchasing power parity (PPP), electricity price and the share of renewables currently in the national energy mix.

Specifically, in regard to the national "energy culture" variables, these are constructed from survey responses to three 5-point Likert scale questions, averaged over all survey respondents within each BSR country. We compute the standard deviation of these responses at the national level to proxy for the range of viewpoints on critical energy issues within a given national context. We call these variables

Table 4.4 Number of respondents per sampled country, choice options available for each respondent and final choices selected from respondents.

\begin{tabular}{lccc}
\hline Country & $\begin{array}{l}\text { Number of } \\
\text { respondents }\end{array}$ & $\begin{array}{l}\text { Investment options } \\
\text { available* }\end{array}$ & Final choice responses \\
\hline Denmark & 604 & 14,496 & 4,832 \\
Estonia & 605 & 14,520 & 4,840 \\
Finland & 604 & 14,496 & 4,832 \\
Germany & 603 & 14,472 & 4,824 \\
Latvia & 600 & 14,400 & 4,800 \\
Lithuania & 601 & 14,424 & 4,808 \\
Norway & 603 & 14,472 & 4,824 \\
Poland & 602 & 14,448 & 4,816 \\
Sweden & 603 & 14,472 & 4,824 \\
BSR & 5,425 & 130,200 & 43,400 \\
\hline
\end{tabular}

Source: authors' elaboration based on individual participant responses to the DCE survey.

*These refer to the final number of choice options disclosed to the sample of respondents in each country: at the conclusion of the survey each individual survey respondent had seen a total of 24 investment options to select from. These were distributed into eight choice tasks with three options per task. 
72 Pons-Seres de Brauwer and Cohen

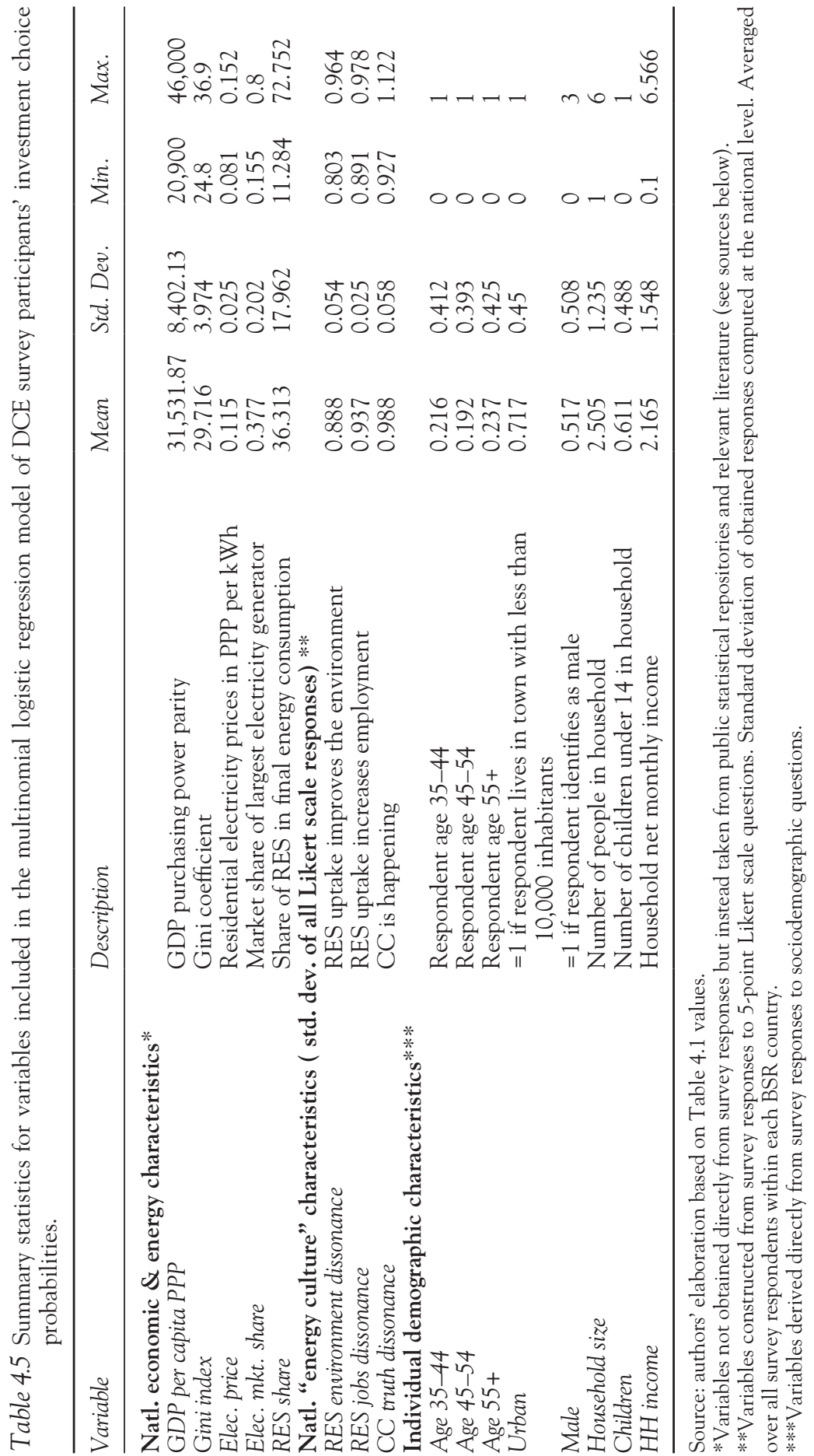




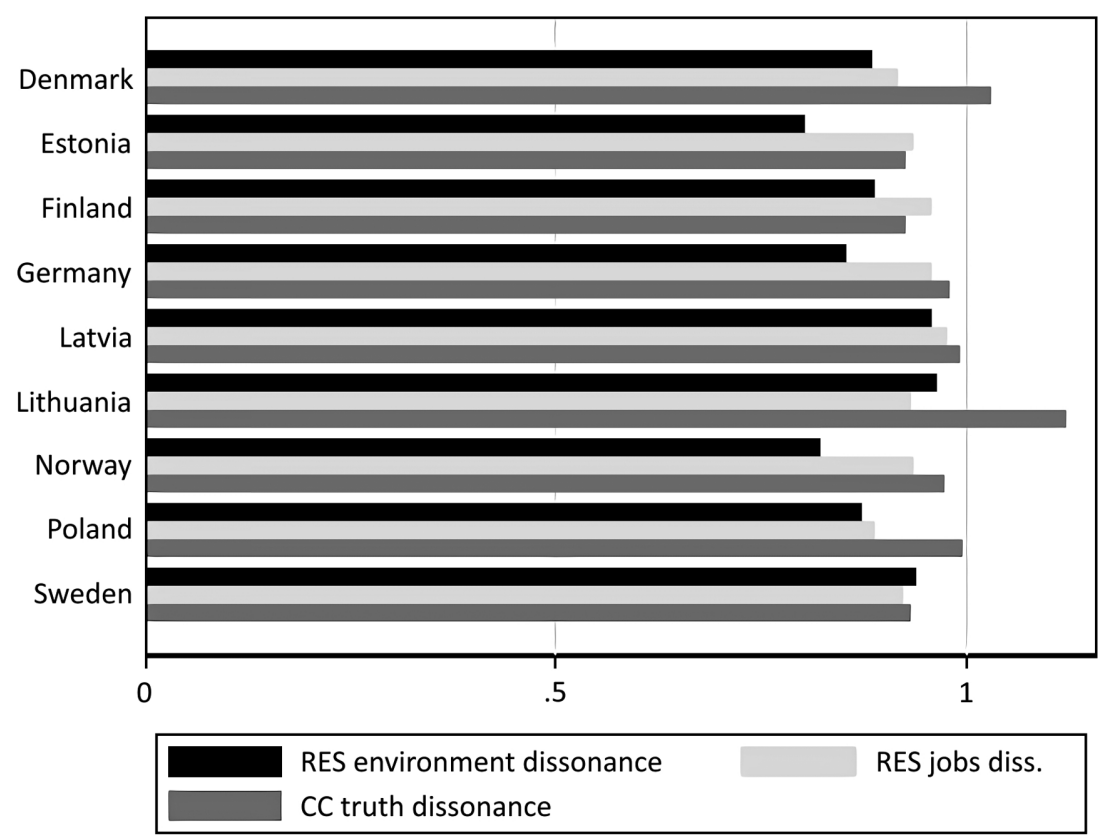

Figure 4.3 Cross-country comparison of respondent dissonance to three main variables illustrative of national energy cultures of BSR nations. Source: authors' elaboration based on survey responses.

"dissonance," as higher values denote energy cultures with a wider heterogeneity of viewpoints and therefore less societal consensus (see Figure 4.3). We observe that the main variation (i.e. respondent dissonance) in these variables across the BSR is in the belief that climate change is happening, with some notable variation in the dissonance on the belief that RE technologies improve the environment. We hypothesise that higher dissonance levels in the national energy culture are posited to reduce feelings of social cohesion and collective action around climate and energy objectives. Thus, citizens in nations with higher dissonance would manifest a decreased willingness to co-invest in a CRE. This hypothesis is tested through a multinomial logistic regression analysis in the proceeding section.

\section{Analysis and results}

Following the DCE survey description outlined in the previous section, the analysis in this section showcases a) descriptive results of the DCE survey responses for each BSR country and b) results stemming from a multinomial logistic regression that estimates the association of socio-economic trends, energy cultures and individual demographic factors (Table 4.5) with BSR citizens' willingness to cofinance CRE developments. ${ }^{5}$ 


\section{Pons-Seres de Brauwer and Cohen}

In doing so, the analytical exercise reported hereafter allows for an empirical investigation of certain facets of the "community-as-investor" dimension of the social acceptance of renewables' innovation (see Figure 4.2).

\section{Descriptive analysis of DCE survey responses}

The 43,400 choice responses obtained from the DCE survey are summarised by the share (percentage) of respondents who chose an investment option at least once throughout the DCE and the total share (percentage) of investment options selected by respondents in each BSR country (see Table 4.6).

Descriptive results indicate an elevated interest expressed by respondents for co-investing in CRE developments via collective finance and co-ownership schemes: $74 \%$ of survey participants selected at least one investment option and further chose to co-invest in $53 \%$ of choice tasks. These initial results thus point towards a substantial acceptance from BSR citizens for CRE opportunities.

Specifically, survey countries with a low or non-existent CRE culture (see Table 4.1) and showcasing high acceptance rates (i.e. $>50 \%$ - Estonia, Lithuania, Norway, Poland) may be indicative of citizens' favourable predisposition to partake in novel co-investment schemes on CRE initiatives within their communities. This may be particularly the case for countries with acutely low RES installed capacities per capita (i.e. Estonia, Lithuania and Poland) ${ }^{6}$ and thus where acceptance concerns stemming from new RE infrastructure development are not yet consolidated (Cohen et al., 2016).

Survey countries with an emerging or robust track-record on cooperative association (and thus with a strong CRE culture) yet manifesting low acceptance rates (i.e. $<50 \%$ - Denmark, Finland, Germany and Sweden) may be illustrative of a more cautious co-investment behaviour due to perceived small-scale energy investment risks derived from a combination of prohibitive capital investment requirements (Bauwens, Gotchev and Holstenkamp, 2016; Laybourn-Langton,

Table 4.6 Descriptive statistics of responses to investment options in the BSR.

\begin{tabular}{lll}
\hline Country & $\begin{array}{l}\text { \% of respondents selecting at } \\
\text { least one investment option }\end{array}$ & $\begin{array}{l}\text { Total \% of investment options } \\
\text { selected }\end{array}$ \\
\hline Denmark & $64 \%$ & $44 \%$ \\
Estonia & $91 \%$ & $84 \%$ \\
Finland & $74 \%$ & $46 \%$ \\
Germany & $74 \%$ & $49 \%$ \\
Latvia & $68 \%$ & $44 \%$ \\
Lithuania & $80 \%$ & $58 \%$ \\
Norway & $75 \%$ & $52 \%$ \\
Poland & $76 \%$ & $55 \%$ \\
Sweden & $64 \%$ & $44 \%$ \\
BSR & $74 \%$ & $53 \%$ \\
\hline
\end{tabular}

Source: authors. 
2016), strict spatial planning criteria (McLaren Loring, 2007; Bauwens, Gotchev and Holstenkamp, 2016), lengthy permitting procedures (Hildebrandt, 2019), expensive legal disputes (WindEurope, 2019), unaffordable grid access fees (Ruggiero, Martiskainen and Onkila, 2018) and increasingly stringent RE compensation mechanisms (Wierling et al., 2018), among others.

Alternatively for Latvia, a country with a low/non-existent CRE culture and acceptance rate $(<50 \%)$, survey responses may shed additional light on the findings reported by Leiren et al. (2020), which found GHG emission reductions from wind energy infrastructure the most salient factor driving the acceptance of local communities in the country. While our investment offerings articulated the specific economic benefits stemming from CRE co-investments, they omitted the positive environmental impacts stemming from such co-investment. In light of Leiren et al.'s (2020) findings, a more explicit articulation of our investment proposition formulated around the positive environmental impact of CRE could potentially yield a more favourable predisposition to co-invest in CRE developments from Latvian citizens.

While these initial observations may be indicative of BSR citizens' propensity to partake in socially innovative forms of CRE co-financing, it is important to note that the DCE survey design assumes full (albeit imperfect) access to robust market information from survey participants and explicitly communicates a risk-free and profit-guaranteed financial return. Critically, in spite of the genuine interest that survey respondents may have manifested for any investment option, these additional design elements most likely remain a crucial driving factor underlying the generalised high acceptance manifested for the investment options displayed in the survey.

This is an important detail that we further reflect on in our discussion section, as it touches directly on the relevance that different RE policy support instruments have for (de)incentivising more actor-diverse RE development pathways through, among others, citizen-financed CRE formats across the BSR. It may thus have far-reaching implications for ongoing legislative efforts underlying the provision of supportive governance and regulatory frameworks captured under NECPs.

\section{Multinomial logistic regression: analytical outputs}

Building on the respondents' heterogeneous levels of expressed interest in CRE co-investment schemes, we conduct multinomial logistic regressions in order to estimate the relationships that the different characteristics depicting national socio-economic trends, energy cultures and individual demographic factors have with BSR citizens' willingness to collectively finance CRE-based developments. The resulting model estimates the latent probability of an individual's choice for an investment option as a function of the options' unique combination of different financial and operational attributes as outlined in Table 4.3. The estimation of the multinomial logistic model is reported as marginal effects of a unit increase of each variable on the individual's choice probability to select an 


\section{Pons-Seres de Brauwer and Cohen}

investment option to co-finance a CRE development. Positive marginal effects indicate a favourable influence of a variable on the respondent's choice probability. Alternatively, negative marginal effects indicate an adverse influence on the respondent's choice probability.

Importantly, we consider proxy variables with a p-value of less than 0.1 to have a statistically significant marginal effect (see Table 4.7).

Results from the multinomial logistic regression show that the average BSR citizen manifests a slight priority for solar parks over wind farms as the preferred $\mathrm{RE}$ installation to co-finance. However, this observation is likely highly contextdependent and as such increased heterogeneity may be expected when assessing country-specific outputs, as explored in Cohen et al. (2019).

In spite of this first appraisal, it is important to reiterate that our analytical efforts do not focus on elucidating the relative effects of the investment options' financial and operational attributes (see Table 4.3) on the respondent's manifested co-investment choice probabilities and decision-making. ${ }^{7}$ Instead, our primary interest concerns the relative influence that certain socio-economic, energy culture and demographic factors constitutive of a nation-wide community

Table 4.7 Multinomial logit model-estimated marginal effects of selected variables on choice probability for selecting an investment option.

\begin{tabular}{llll}
\hline Variable & Marg. Eff. & Std. Err. & p-value \\
\hline National economic Ė energy characteristics & & & \\
GDP PPP & $1.5 \mathrm{E}-05$ & $1.8 \mathrm{E}-06$ & 0.000 \\
Gini index & 0.09754 & 0.0092 & 0.000 \\
RES share & 0.00397 & 0.0007 & 0.000 \\
Elec. mkt. share & -0.50130 & 0.0830 & 0.000 \\
Elec. price & -6.08963 & 0.5889 & 0.000 \\
National "energy culture" characteristics & & & \\
RES jobs dissonance & -5.94739 & 0.6004 & 0.000 \\
CC truth dissonance & -3.84145 & 0.4497 & 0.000 \\
RES environ. dissonance & -3.66271 & 0.2334 & 0.000 \\
Individual demographic characteristics & & & \\
Male & 0.08642 & 0.0122 & 0.000 \\
HH income & 0.02428 & 0.0060 & 0.000 \\
Urban & 0.01928 & 0.0135 & 0.155 \\
HH size & 0.00689 & 0.0063 & 0.271 \\
Children & -0.01157 & 0.0158 & 0.464 \\
Age 35-44 & -0.06274 & 0.0170 & 0.000 \\
Age 4-54 & -0.10491 & 0.0181 & 0.000 \\
Age 55+ & -0.14687 & 0.0184 & 0.000 \\
Solar tech. & 0.01000 & 0.0035 & 0.004 \\
Capital requirement & $-5.20 \mathrm{E}-06$ & $3.40 \mathrm{E}-06$ & 0.130 \\
\hline
\end{tabular}

Note II: Sample size $(\mathrm{N})=5,425$ respondents and 43,400 choice responses.

Note I: Highlighted rows indicate statistical significance at the 10\% level. Model estimation includes all financial/operational attributes outlined in Table 4.3 yet these estimates are not reported here as our primary focus is on nation-wide community characteristics (as opposed to project-specific attributes).

Source: authors. 
of citizens have in shaping individuals' willingness to collectively finance CREbased developments across the BSR. In that respect, the analytical outputs stemming from the regression analysis indicate a number of statistically significant marginal effects, which we interpret through the "community-as-investor" lens outlined in the conceptual framework in section 2 .

\section{National economic and energy characteristics}

First, we observe a significant negative marginal effect of GDP PPP on the likelihood of CRE co-investment uptake from citizens across the BSR. Interestingly, across the BSR, nations with higher Gini index of wealth inequality show higher acceptance of CRE schemes, with every unit increase in Gini leading to a 9.7\% increase in the willingness of BSR citizens to co-invest in CRE schemes. When taken together, these two observations plausibly suggest that it is not only a country's aggregated wealth - but rather its distribution - that prominently associates with the propensity of its citizens to collectively invest in community-based forms of RE generation across the BSR. Importantly, both GDP and Gini index findings may be indicative of the fact that CRE schemes enable a lower required investment amount for individuals to co-own RE generation assets, as opposed to a fully self-owned scheme (Cohen et al., 2019; Haggett and Aitken, 2015; Hall, Foxon and Bolton, 2016; Yildiz, 2014; Yildiz et al., 2015), thus enabling population segments with lower financial means to partake in, and benefit from, collective investment and co-ownership schemes in contrast to more traditional, larger single-investment schemes or private single-owner RE generation systems (de Brauwer and Cohen, 2020).

Second, a higher RES share in a country's final energy consumption appears to associate with an increased propensity to co-invest in CRE, on average. Specifically, every additional percentage point increase of the RES share in final energy consumption yields a corresponding $0.4 \%$ average increase in the willingness to co-invest from BSR citizens. As such, BSR countries with higher RES market penetrations may be more likely to trigger citizen-financed CRE schemes than neighbouring countries.

Thirdly, BSR countries with more restrictive energy markets - in the form of either higher market concentrations of leading electricity generators or higher household electricity prices - tend to yield lower citizen co-investment probabilities in CRE schemes. Specifically, every additional percentage point increase in the market share of the largest electricity generator triggers a 50\% decrease in the average BSR citizen's probability to co-invest. Furthermore, higher electricity prices are strongly associated with lower willingness to invest, with every 1 Euro cent increase in price triggering a $6.1 \%$ decrease in willingness to co-invest. ${ }^{8}$

\section{National "energy culture" characteristics}

Turning to the energy culture characteristics, we attempt to use these as a means to forward a better understanding of the relative influence that community 
cohesion/dissension on different energy-related aspects has on driving an individual's propensity to invest in energy socio-technical innovations such as those disclosed under the CRE concept.

For our particular purposes, we align with Walker (2008) in adopting a broad view of "community," in our case illustrating the nation state where a given individual resides. This enables us to assess the relative influence that country-level social cohesiveness has in shaping an individual's decision to co-invest in CRE. With this in mind, we take the "dissonance" variables (see Figure 4.3) as proxy values to measure the relative social cohesion across the sample countries (as these showcase the range of viewpoints with respect to the energy culture of a nation-wide community of citizens) and test the hypothesis that higher dissonance levels in the national energy culture are posited to reduce BSR citizens' willingness to co-invest in a CRE initiative.

Across the BSR, dissonance within the national community's energy culture is shown to negatively drive CRE co-investment probability choices for all three "energy culture" proxy variables (see Table 4.7). Specifically, individual dissonance regarding the impact of RES uptake on job creation showcases the strongest negative marginal effect on co-investor acceptance for CRE, with a 0.01 unit increase in dissonance associated with a $5.9 \%$ point reduction in the probability of CRE co-investing. Similar findings are observed for individual dissonance on the veracity of climate change $(-3.8 \%$ points $)$ and with respect to the environmental benefits from increased RES adoption ( $-3.7 \%$ points).

These findings substantiate our hypothesis that higher dissonance levels in the national energy culture can reduce the willingness to co-invest in CRE initiatives. As such, BSR countries with increased societal discrepancy on energy and climate issues may tend to disfavour co-investment schemes on CRE, while BSR countries with reduced discrepancy may tend to favour CRE co-investment schemes.

\section{Individual demographic characteristics}

We complement the insights disclosed above with a set of demographic characteristics furthering a more rounded appraisal of the individual members constitutive of a nation-wide community of citizens.

As expected, household disposable income exerts a strong positive marginal effect on the acceptance of CRE co-investment offerings from citizens across the BSR. Specifically, for every $€ 100$ increase in household income the probability to invest in CRE is $2.4 \%$ points higher.

Age appears as a relevant driver in choice probability formation across the entire sample, with respondents aged 35-44 more accepting of co-investment options than older respondents aged 45-54 and 55+. Such an observation may suggest reduced risk aversion (or a willingness to wait for more mature investments) from younger groups, who are more inclined to the possibility of coinvesting in socio-technically innovative forms of RES diffusion. 
Finally, female respondents on average are less likely to invest in the options offered. This translates into an $8.6 \%$ reduced likelihood on the probability to coinvest in CRE schemes for female respondents.

\section{Discussion and conclusion}

The analytical outputs outlined in the preceding section showcase an overall high interest expressed by BSR citizens to partake in socio-technically innovative forms of CRE co-financing. However, our use of country-level variables in the logistic regression model opens the door for country-level factors that were left out of the model to induce omitted variable bias. As such, we cannot interpret these country-level variables causally and instead note that the results stemming from our analytical exercise suggest a heterogeneity of driving influences both fostering and hindering the community-as-investor acceptance of citizens for partaking in CRE developments across the BSR. As such, future work could narrow down the community boundaries and consider the role of smaller community units (e.g. regional/provincial jurisdictions, municipalities, neighbourhoods) in facilitating citizen-financed CRE schemes, as well as develop in greater depth the number of driving influences underpinning each set of variables outlined in Table 4.7.

Furthermore, it is critical to reiterate here that our empirical findings rest on a DCE survey design that explicitly communicated to respondents a risk-free and profit-guaranteed financial return. ${ }^{9}$ These facts, paired with the availability of multiple investment options, may substantiate the elevated acceptance manifested for the investment options being offered (see Table 4.6).

Approximating the DCE conditions above would thus require NECP legislative efforts across the BSR to risk-proof citizen investments by ensuring the bankability of CRE-oriented concepts. Relevant (yet non-exhaustive) measures could include:

- Facilitating easy access to government-backed finance (e.g. via low interest or interest-free public loans, capital subsidies, loan guarantees);

- Harmonised fiscal incentives (e.g. via production tax exemptions to clean fuel commodities commensurate with their $\mathrm{CO}_{2}$ emissions avoidance potential and in consonance with domestic carbon taxes);

- $\quad$ Long-term remuneration schemes (e.g. via feed-in policies).

These and other RES support policies may contribute to advance a risk-minimised environment conducive to the participation of more socially innovative but riskexposed CRE stakeholders such as energy cooperatives. In that respect, the progressive evolution towards more stringent remuneration mechanisms across the EU - culminated by the latest policy trend to substitute Feed-in-Tariff (FiT) schemes for competitive tendering in the form of RE auctions - runs diametrically opposite to such an objective. The disruptiveness of such a policy shift for 
citizen-financed CRE can be observed in countries with long-standing traditions on cooperative association such as Denmark and Germany, often considered frontrunners in fostering CRE-based developments (Danielsen, 1995; Jørgensen, 1995; Kemp, Rip and Schot, 2001; Debor, 2018; Roberts, 2020).

In 2002, over 700 energy cooperatives owned approximately $40 \%$ of all wind power installations in Denmark, with up to 150,000 participating households across the country (Bauwens, Gotchev and Holstenkamp, 2016; Wierling et al., 2018). An additional $40 \%$ was owned by single individuals (mostly farmers) and the remaining $20 \%$ by energy utilities (Bauwens, Gotchev and Holstenkamp, 2016). However, between 2000-2003 Denmark enacted legislation to substitute its FiT-based remuneration scheme for market premiums, lowering FiT payments by $25 \%$ along with a reduction in their duration (Bauwens, Gotchev and Holstenkamp, 2016; Roberts, 2020). This resulted in a substantial decrease in wind energy cooperatives. In effect, by 2004 the number of households owning shares in energy cooperatives had declined to 100,000 and by 2009 to 50,000 (Mendonça, Lacey and Hvelplund, 2009). By 2010, no more than 15\% of wind energy assets were owned by cooperatives, and by 2017 less than 200 wind energy cooperatives remained operational across the country (Wierling et al., 2018).

Along similar lines, in 2014 Germany hosted almost 800 energy cooperatives, the largest number from any EU country (Wierling et al., 2018). By 2016, German citizens owned $42 \%$ of the country's installed renewable power capacity (trend:research, 2017). The prolonged use of FiTs throughout the 2000s contributed amply to this outcome, triggering an eleven-fold increase in communitybased cooperative associations between 2000-2014 (Leiren and Reimer, 2018; Wierling et al., 2018). In 2014, Germany transposed EU legislation to substitute its FiT-based remuneration scheme for an auction-based system of competitive tendering. On its first 6 pilot auction rounds between 2015-2016, only 0.8\% of bids were won by energy cooperatives, triggering the dissolution of over 163 RE cooperatives (Bundesnetzagentur, 2015a, 2015b, 2016a, 2016b, 2016c, 2017; Beermann and Tews, 2017). In light of such bleak prospects, in 2017 the German Federal Network Agency issued an auction round with special provisions for community energy associations, yet a loosely formulated definition of "citizen energy companies" (CECs) enabled corporate developers to rather easily qualify as CECs when in fact their operational structure and financial capital was not reflective of such a legal form (Tews, 2018; Gsänger and Karl, 2020). Furthermore, only 14 new energy cooperatives were created in 2019 as opposed to 139 newly founded cooperatives in 2013 (Roberts, 2020).

Denmark's and Germany's experiences thus offer a stark reminder of the increasing policy risk derived from competition-inducing regulatory frameworks for fostering an actor-diverse energy transition based on the participation of citizens as co-investors of socially innovative RE generation concepts locally embedded around participatory practices. In that respect, the increased price volatility and revenue uncertainty brought about with the progressive evolution from fixed FiTs, to market premiums and ultimately towards auction schemes imposes too high a barrier for unlocking citizen-financed CRE formats, as these do not tend 
to be driven entirely by profit-seeking enterprises but by communal initiatives with other social and environmental motivations (Breukers and Wolsink, 2007; Bomberg and McEwen, 2012; Rogers et al., 2012a, 2012b). BSR countries with limited experience in CRE-based policy development may thus find the Danish and German experiences instrumental in their legislative efforts to design responsive NECP proposals rewarding - rather than penalising - citizen involvement in national energy decarbonisation efforts, as required under the EU-CEP. ${ }^{10}$

The analytical enquiry reported herein attempts to bridge the potential information deficit regarding individual preference formation with respect to citizenfinanced forms of CRE generation. The guiding objective of this enquiry has therefore been to contribute to an empirically validated knowledge source base for substantiating citizen-centric NECP design efforts and, in doing so, contribute to foster a socially legitimised diffusion of renewables' innovation across the BSR.

Ultimately, our conceptual contribution and empirical enquiry jointly attempt to support BSR countries in their efforts to address and operationalise the European Union's ambition to have citizens “take ownership of the energy transition, benefit from new technologies to reduce their bills, [and] participate actively in the market" (European Commission, 2015, p. 2).

\section{Acknowledgements}

The authors would like to acknowledge the financial support of the European Union's Horizon 2020 Research and Innovation Programme for funding the project SMARTEES [Grant agreement No. 763912] and the project MISTRAL under the Marie Skłodowska-Curie Actions [Grant agreement No. 813837]. The views and opinions expressed in this publication are the sole responsibility of the authors and do not necessarily reflect the views of the European Commission. Research design, data collection and analysis remain within the sole responsibility of the authors, with all remaining errors being the authors' own.

\section{Notes}

1 These refer to the official definitions of "renewable energy communities" (RECs) and "citizen energy communities" (CECs) disclosed under the recast Renewable Energy Directive - RED II ((EU) 2018/2001) and the recast Internal Electricity Market Directive - IEMD ((EU) 2019/944), respectively. For details see https://ec.europa.eu/ energy/topics/energy-strategy/clean-energy-all-europeans_en.

2 With the exception of Germany, where various empirical studies have been conducted on the driving motivations behind citizen participation in community-driven forms of RE generation. Examples include Yildiz (2014) for financial motivations and Kalkbrenner \& Roosen (2016) for social and environmental drivers. Furthermore, other studies have also conducted similar enquiries - albeit to a lesser extent - under a Danish context (e.g. Johansen \& Emborg, 2018).

3 As opposed to the object of acceptance which, in this case, would be the socio-technical innovation itself (i.e. CRE-based development or legal entity such as an energy cooperative). 
4 It is important to note that the outlined sampling procedure was conducted to ensure representative samples for each BSR country. Therefore, the resulting final sample is not weighted according to national population.

5 Important to note that our analytical exercise does not address the relative effect of the investment options' financial and operational attributes (Table 4.3) in shaping respondents' manifested choice probabilities, as this is dealt in greater detail in Cohen et al. (2019) and de Brauwer \& Cohen (2020).

6 In 2018 Estonia (0.48 kW/capita), Lithuania (0.3) and Poland (0.22) had the 6th, 4th and 2nd lowest RES installed capacities per capita of the EU-28, respectively (IRENA, 2019; Eurostat, 2020g).

7 These are addressed in greater detail in Cohen et al. (2019) and de Brauwer \& Cohen (2020).

8 Specifically with respect to household electricity prices, it is important to note that these do not drive the return on the investment disclosed in the investment options presented to survey respondents, since the rate of return is specified as a differentiated attribute on the choice experiment. The observed influence of household electricity prices highlighted here therefore relates to structural characteristics of national energy markets aggregated across the BSR.

9 While not originally conceived to mirror a specific policy framework, these additional design elements are representative conditions illustrating the risk-contained and financially enabling regulatory environment facilitated under a fixed Feed-in-Tariff (FiT) system, whereby a stable remuneration is guaranteed to RES-E operators based on a combination of long-term (e.g. 20 years) fixed electricity prices, along with "priority dispatch" guarantees (Lipp, 2007; Fouquet and Johansson, 2008; Cointe and Nadaï, 2018).

10 Poland's NECP, for instance, has a target to facilitate the creation of around 300 "community energy clusters" by 2030, yet existing regulation appears ill-suited in generating the necessary legal, financial and regulatory certainty to expedite cluster developments across its jurisdiction (Dragan, 2020).

\section{References}

Bauwens, T. (2016) "Explaining the diversity of motivations behind community renewable energy," Energy Policy. Amsterdam: Elsevier, 93, pp. 278-90. doi: 10.1016/j. enpol.2016.03.017.

Bauwens, T. and Devine-Wright, P. (2018) "Positive energies? An empirical study of community energy participation and attitudes to renewable energy," Energy Policy. Amsterdam: Elsevier, 118, pp. 612-25. doi: 10.1016/J.ENPOL.2018.03.062.

Bauwens, T., Gotchev, B. and Holstenkamp, L. (2016) "What drives the development of community energy in Europe? The case of wind power cooperatives," Energy Research and Social Science. Amsterdam: Elsevier, 13, pp. 136-47. doi: 10.1016/j.erss.2015.12.016.

Beermann, J. and Tews, K. (2017) "Decentralised laboratories in the German energy transition. Why local renewable energy initiatives must reinvent themselves," Journal of Cleaner Production. Amsterdam: Elsevier, 169, pp. 125-34. doi: 10.1016/j. jclepro.2016.08.130.

Bomberg, E. and McEwen, N. (2012) "Mobilizing community energy," Energy Policy, Amsterdam: Elsevier, 51, pp. 435-44. doi: 10.1016/j.enpol.2012.08.045.

Bourcet, C. and Bovari, E. (2020) "Exploring citizens' decision to crowdfund renewable energy projects: Quantitative evidence from France," Energy Economics. Amsterdam: Elsevier, 88, p. 104754. doi: 10.1016/j.eneco.2020.104754. 
Breukers, S. and Wolsink, M. (2007) "Wind power implementation in changing institutional landscapes: An international comparison," Energy Policy. Amsterdam: Elsevier, 35(5), pp. 2737-50. doi: 10.1016/J.ENPOL.2006.12.004.

Brummer, V. (2018) "Community energy - Benefits and barriers: A comparative literature review of community energy in the UK, Germany and the USA, the benefits it provides for society and the barriers it faces," Renewable and Sustainable Energy Reviews. Amsterdam: Elsevier, 94, pp. 187-96. doi: 10.1016/j.rser.2018.06.013.

Bundesnetzagentur (2015a) Hintergrundpapier: Ergebnisse der ersten Ausschreibungsrunde für Photovoltaik (PV) - Freiflächenanlagen vom 15. April 2015. Bonn, DE. Available at: https:/www.bundesnetzagentur.de/SharedDocs/Downloads/DE/Sachgebiete/Energie/ Unternehmen_Institutionen/ErneuerbareEnergien/PV-Freiflaechenanlagen/ Hintergrundpapiere/Hintergrundpapier_PV-FFA_Runde1.html?nn=720866 (Accessed: 15 April 2021).

Bundesnetzagentur (2015b) Hintergrundpapier: Ergebnisse der zweiten Ausschreibungsrunde für Photovoltaik (PV) - Freiflächenanlagen vom 1. August 2015. Bonn, DE. Available at: https:/www.bundesnetzagentur.de/SharedDocs/Downloads/DE/Sachgebiete/Energie/ Unternehmen_Institutionen/ErneuerbareEnergien/PV-Freiflaechenanlagen/ Hintergrundpapiere/Hintergrundpapier_PV-FFA_Runde2.html?nn=720866 (Accessed: 15 April 2021).

Bundesnetzagentur (2016a) Hintergrundpapier: Ergebnisse der fünften Ausschreibungsrunde für Photovoltaik(PV)-Freiflächenanlagen vom 01. August 2016. Bonn, DE. Available at: https:/www.bundesnetzagentur.de/SharedDocs/Downloads/DE/Sachgebiete/Energie/ Unternehmen_Institutionen/ErneuerbareEnergien/PV-Freiflaechenanlagen/ Hintergrundpapiere/Hintergrundpapier_01_08_2016.html?nn=720866 (Accessed: 15 April 2021).

Bundesnetzagentur (2016b) Hintergrundpapier: Ergebnisse der vierten Ausschreibungsrunde für Photovoltaik (PV)-Freiflächenanlagen vom 1. April 2016. Bonn, DE. Available at: https://www.bundesnetzagentur.de/SharedDocs/Downloads/DE/Sachgebiete/Energie/ Unternehmen_Institutionen/ErneuerbareEnergien/PV-Freiflaechenanlagen/ Hintergrundpapiere/Hintergrundpapier_01_04_2016.html?nn=720866 (Accessed: 15 April 2021).

Bundesnetzagentur (2016c) Hintergrundpapier: Vorläufi ge Ergebnisse der dritten Ausschreibungsrunde für Photovoltaik (PV)-Freifl ächenanlagen vom 1. Dezember 2015. Bonn, DE. Available at: https://www.bundesnetzagentur.de/SharedDocs/Downloads /DE/Sachgebiete/Energie/Unternehmen_Institutionen/ErneuerbareEnergien/PV -Freiflaechenanlagen/Hintergrundpapiere/finalesHintergrundpapier_01_12_2015 .html?nn=720866 (Accessed: 15 April 2021).

Bundesnetzagentur (2017) Hintergrundpapier: Ergebnisse der sechsten Ausschreibungsrunde für Photovoltaik(PV)-Freilächenanlagen vom 01. Dezember 2016. Bonn, DE. Available at: https://www.bundesnetzagentur.de/SharedDocs/Downloads/DE/Sachgebiete/Energie/ Unternehmen_Institutionen/ErneuerbareEnergien/PV-Freiflaechenanlagen/ Hintergrundpapiere/Hintergrundpapier_01_12_2016.html?nn=720866 (Accessed: 15 April 2021).

Caiati, G., Marta, F. L. and Quinti, G. M. (2019) Policy Brief on "Social Innovation in Energy Transition" in Action. Available at: http://local-social-innovation.eu/ (Accessed: 24 September 2020).

Cajaiba-Santana, G. (2014) "Social innovation: Moving the field forward. A conceptual framework," Technological Forecasting and Social Change. Amsterdam: Elsevier, 82(1), pp. 42-51. DOI: 10.1016/j.techfore.2013.05.008. 
Capellán-Pérez, I., Johanisova, N., Young, J. and Kunze, C. (2020) "Is community energy really non-existent in post-socialist Europe? Examining recent trends in 16 countries," Energy Research and Social Science. Amsterdam: Elsevier, 61, p. 101348. DOI: 10.1016/j. erss.2019.101348.

Cohen, J., Azarova, V., Kollmann, A. and Reichl, J. (2019) "Preferences for community renewable energy investments in Europe: A choice experiment across 31 European nations," Zenodo. p. 1-59. DOI: 10.5281/zenodo.3556330.

Cohen, J., Moeltner, K., Reichl, J. and Schmidthaler, M. (2016) "An empirical analysis of local opposition to new transmission lines across the EU-27," The Energy Journal, Houston: IAEE, 37(3), pp. .59-82. DOI: 10.5547/01956574.37.3.jcoh.

Cointe, B. and Nadaï, A. (2018) Feed-in Tariffs in the European Union : Renewable Energy Policy, the Internal Electricity Market and Economic Expertise. Edited by B. Cointe and A. Nadaï. Palgrave Macmillia. Available at: https:/www.palgrave.com/ gp/ book/9783319763200 (Accessed: 4 June 2020).

Council of European Energy Regulators (2018) Status Review of Renewable Support Schemes in Europe for 2016 and 2017. C18-SD-63-03. Available at: https:/www.ceer .eu/1519.

Creamer, E., Aiken, G. T., van Veelen, B., Walker, G. and Devine-Wright, P. (2019) "Community renewable energy: What does it do? Walker and Devine-Wright (2008) ten years on," Energy Research EF Social Science. Amsterdam: Elsevier, 57, p. 101223. DOI: $10.1016 /$ j.erss.2019.101223.

Danielsen, O. (1995) "Large-scale wind power in Denmark," Land Use Policy. Oxford: Pergamon Press, 12(1), pp. 60-2. doi: 10.1016/0264-8377(95)90075-D.

de Brauwer, C. P. S. and Cohen, J. (2020) "Analysing the potential of citizen-financed community renewable energy to drive Europe's low-carbon energy transition," Renewable and Sustainable Energy Reviews. Amsterdam: Elsevier, 133, p. 110300. DOI: 10.1016/j.rser.2020.110300.

Debor, S. (2018) Multiplying Mighty Davids? The Influence of Energy Cooperatives on Germany's Energy Transition. Cham: Springer International Publishing (Contributions to Economics). DOI: 10.1007/978-3-319-77628-6.

Dragan, D. (2020) "Legal barriers to the development of energy clusters in Poland," European Energy and Environmental Law Review. Alphen aan den Rijn: Kluwer Law International, 29(1), pp. 14-20. Available at: https://findit.dtu.dk/en/catalog/ 2594609048 (Accessed: 29 September 2020).

European Commission (2015) ENERGY UNION PACKAGE. COMMUNICATION FROM THE COMMISSION TO THE EUROPEAN PARLIAMENT, THE COUNCIL, THE EUROPEAN ECONOMIC AND SOCIAL COMMITTEE, THE COMMITTEE OF THE REGIONS AND THE EUROPEAN INVESTMENT BANK. A Framework Strategy for a Resilient Energy Union w. 52015DC0080. Brussels. Available at: https://eur -lex.europa.eu/legal-content/EN/TXT/?uri=CELEX:52015DC0080.

Eurostat (2019a) "Baseline projections: Demographic balances and indicators." Available at: http://data.europa.eu/euodp/data/dataset/c9QfsU6YkvrjAIHYKmHp3w.

Eurostat (2019b) "Distribution of income by quantiles - EU-SILC and ECHP surveys." Available at: https://ec.europa.eu/eurostat/web/products-datasets/product?code =ilc_ di01 (Accessed: 12 March 2019).

Eurostat (2019c) "Population by age group." Available at: https://ec.europa.eu/eurostat/ web/ products-datasets/product?code=tps00010 (Accessed: 12 March 2019).

Eurostat (2019d) "Purchasing power adjusted GDP per capita." Brussels, BE. Available at: https://ec.europa.eu/eurostat/web/products-datasets/-/sdg_10_10. 
Eurostat (2019e) "Women per 100 men." Available at: https://ec.europa.eu/eurostat/web/ products-datasets/product?code=tps00011 (Accessed: 12 March 2019).

Eurostat (2020a) "Arrears on utility bills - EU-SILC survey." Brussels, BE. Available at: https://ec.europa.eu/eurostat/en/web/products-datasets/-/ILC_MDES07.

Eurostat (2020b) "Electricity prices for household consumers - Bi-annual data (from 2007 onwards)." Brussels, BE. Available at: https://ec.europa.eu/eurostat/en/web/products -datasets/-NRG_PC_204.

Eurostat (2020c) "Gini coefficient of equivalised disposable income - EU-SILC survey." Brussels, BE. Available at: https://ec.europa.eu/eurostat/web/products-datasets/-/ tessi190.

Eurostat (2020d) "Inability to keep home adequately warm - EU-SILC survey." Brussels, BE. Available at: https://ec.europa.eu/eurostat/web/products-datasets/product?code $=$ ilc_mdes 01 .

Eurostat (2020e) "Market share of the largest generator in the electricity market - Annual data." Brussels, BE. Available at: https://ec.europa.eu/eurostat/web/products-datasets/-/ nrg_ind_331a.

Eurostat (2020f) "Population on 1 January." Available at: https://ec.europa.eu/eurostat/ web/products-datasets/-/tps00001.

Eurostat (2020g) "Share of renewable energy in gross final energy consumption." Brussels, BE. Available at: https://ec.europa.eu/eurostat/web/products-datasets/-/t2020_rd330.

Fouquet, D. and Johansson, T. B. (2008) "European renewable energy policy at crossroads - Focus on electricity support mechanisms," Energy Policy. Amsterdam: Elsevier, 36(11), pp. 4079-92. doi: 10.1016/j.enpol.2008.06.023.

Göpel, M. (2016) The Great Mindshift - How a New Economic Paradigm and Sustainability Transformations Go Hand in Hand, Springer. Cham: Springer International Publishing. DOI: $10.1007 / 978-3-319-43766-8$.

Gsänger, S. and Karl, T. (2020) "Community wind under the auctions model: A critical appraisal," in Uyar, T. S. (ed.), Accelerating the Transition to a 100 Renewable Energy Era. Cham: Springer International Publishing, pp. 233-57. DOI: 10.1007/978-3-030-40738-4_11.

Haggett, C. and Aitken, M. (2015) "Grassroots energy innovations: The role of community ownership and investment," Current Sustainable/Renewable Energy Reports. Basingstoke: Springer Nature, 2(3), pp. 98-104. DOI: 10.1007/s40518-015-0035-8.

Hall, S., Foxon, T. J. and Bolton, R. (2016) "Financing the civic energy sector: How financial institutions affect ownership models in Germany and the United Kingdom," Energy Research Eु Social Science. Amsterdam: Elsevier, 12, pp. 5-15. DOI:10.1016/J. ERSS.2015.11.004.

Hewitt, R. J., Bradley, N., Baggio Compagnucci, A., Barlagne, C., Ceglarz, A., Cremades, R., McKeen, M., Otto, I. and Slee, B. (2019) "Social innovation in community energy in Europe: A review of the evidence," Frontiers in Energy Research. Lausanne: Frontiers Media S.A., 7(APR), p. 31. DOI: 10.3389/fenrg.2019.00031.

Hicks, J. and Ison, N. (2018) "An exploration of the boundaries of "community" in community renewable energy projects: Navigating between motivations and context," Energy Policy. Amsterdam: Elsevier, 113, pp. 523-34. DOI: 10.1016/j.enpol.2017.10.031.

Hildebrandt, M. (2019) "Hard times for wind power," New Energy. Middleton: August. Issue $3 \& 4 / 2019$.

Hoppe, T., Butenko, A. and Heldeweg, M. (2018) "Innovation in the European energy sector and regulatory responses to it: Guest editorial note," Sustainability. Basel: MDPI AG, 10(2), p. 416. DOI: 10.3390/su10020416. 
Hoppe, T. and de Vries, G. (2018) "Social innovation and the energy transition," Sustainability. Basel: MDPI AG, 11(1), p. 141. DOI: 10.3390/su11010141.

Ingold, K., Stadelmann-Steffen, I. and Kammermann, L. (2019) "The acceptance of instruments in instrument mix situations: Citizens' perspective on Swiss energy transition," Research Policy. Amsterdam: Elsevier, 48(10), p. 103694. DOI: 10.1016/j. respol.2018.10.018.

IRENA (2019) Renewable Capacity Statistics 2019. 978-92-9260-123-2. Abu Dhabi, UAE. Available at: publications/2019/Mar/Renewable-Capacity-Statistics-2019 (Accessed: 11 September 2020).

Johansen, K. and Emborg, J. (2018) "Wind farm acceptance for sale? Evidence from the Danish wind farm co-ownership scheme," Energy Policy. Amsterdam: Elsevier, 117, pp. 413-422. DOI: 10.1016/j.enpol.2018.01.038.

Jørgensen, U. (1995) "The Danish wind-turbine story: Technical solutions to political visions ?," in The Danish Wind-Turbine Story: Technical Solutions to Political Visions? Available at: https://orbit.dtu.dk/en/publications/the-danish-wind-turbine-story -technical-solutions-to-political-vi (Accessed: 5 June 2020).

Kalkbrenner, B. J. and Roosen, J. (2016) "Citizens' willingness to participate in local renewable energy projects: The role of community and trust in Germany," Energy Research and Social Science. Amsterdam: Elsevier, 13, pp. 60-70. DOI: 10.1016/j. erss.2015.12.006.

Kemp, R. P. M., Rip, A. and Schot, J. (2001) "Constructing transition paths through the management of niches," in Garud, R. and Karnoe, P. (eds), Path Dependence and Creation. Mahwa and London: Lawrence Erlbaum, pp. 269-99. Available at: https:// research.utwente.nl/en/publications/constructing-transition-paths-through-the -management-of-niches (Accessed: 5 June 2020).

Laybourn-Langton, L. (2016) Community and Local Energy Challenges and Opportunities. Available at: https://www.ippr.org/files/publications/pdf/community-energy_June2016 .pdf.

Leiren, M. D., Aakre, S., Linnerud, K., Julsrud, T. E., Di Nucci, M.-R. and Krug, M. (2020) "Community acceptance of wind energy developments: Experience from wind energy scarce regions in Europe," Sustainability. Basel: MDPI, 12(5), 1754. DOI: 10.3390/su12051754.

Leiren, M. D. and Reimer, I. (2018) "Historical institutionalist perspective on the shift from feed-in tariffs towards auctioning in German renewable energy policy," Energy Research ES Social Science. Amsterdam: Elsevier, 43, pp. 33-40. DOI: 10.1016/J. ERSS.2018.05.022.

Lipp, J. (2007) "Lessons for effective renewable electricity policy from Denmark, Germany and the United Kingdom,” Energy Policy. Amsterdam: Elsevier, 35(11), pp. 5481-95. DOI: 10.1016/j.enpol.2007.05.015.

Lowitzsch, J. (2019) "Financing renewables while implementing energy efficiency measures through consumer stock ownership plans (CSOPs) - The H2020 project SCORE," IOP Conference Series: Earth and Environmental Science, Bristol: IOP Publishing, 290, p. 12051. DOI: 10.1088/1755-1315/290/1/012051.

Lowitzsch, J., Hoicka, C. E. and van Tulder, F. J. (2020) "Renewable energy communities under the 2019 European clean energy package - Governance model for the energy clusters of the future?," Renewable and Sustainable Energy Reviews. Amsterdam: Elsevier, 122, p. 109489. doi: 10.1016/j.rser.2019.109489.

MacCallum, D. (2016) Social Innovation and Territorial Development. Abingdon: Routledge. Available at: https://www.routledge.com/Social-Innovation-and-Territorial -Deve 
lopment-1st-Edition/MacCallum-Haddock-Moulaert/p/book/9781138269941 ?gcli d=CjwKCAjwqpP2BRBTEiwAfpiD-4QY700GOMSpqXZbHf3h8jMuW CaKDtHq2gd FCGHk4zCJqhnQYdiSqBoCdA8QAvD_BwE (Accessed: 5 June 2020).

McLaren Loring, J. (2007) "Wind energy planning in England, Wales and Denmark: Factors influencing project success," Energy Policy. Amsterdam: Elsevier, 35(4), pp. 2648-60. DOI: 10.1016/j.enpol.2006.10.008.

Mendonça, M., Lacey, S. and Hvelplund, F. (2009) "Stability, participation and transparency in renewable energy policy: Lessons from Denmark and the United States," Policy and Society. Elsevier, 27(4), pp. 379-98. DOI: 10.1016/j.polsoc.2009.01.007.

Neumeier, S. (2017) "Social innovation in rural development: Identifying the key factors of success," The Geographical Journal. Hoboken: Wiley-Blackwell, 183(1), pp. 34-46. DOI: 10.1111 /geoj.12180.

Polman, N., Slee, B., Kluvankova, T., Dijkshoorn-Dekker, M. W. C., Nijnik, M., Gežik, V. and Soma, K. (2017) Report D2.1 - Classification of Social Innovations for Marginalized Rural Areas. Available at: www.simra-h2020.eu/wp -content/uploads/2017/09/D2.1 Classification-of-SI-for-MRAs-in-the-target -region.pdf.

REScoop (2020) Community Energy Map. Available at: https://www.rescoop.eu/community -energy-map (Accessed: 9 September 2020).

Roberts, J. (2020) "Power to the people? Implications of the clean energy package for the role of community ownership in Europe's energy transition," Review of European, Comparative Ë International Environmental Law. Hoboken: Wiley-Blackwell, 29(2), pp. 232-44. doi: 10.1111/reel.12346.

Rogers, J. C., Simmons, E. A., Convery, I. and Weatherall, A. (2012a) "Social impacts of community renewable energy projects: Findings from a woodfuel case study," Energy Policy, Amsterdam: Elsevier, 42, pp. 239-47. DOI: 10.1016/j.enpol.2011.11.081.

Rogers, J. C., Simmons, E. A., Convery, I. and Weatherall, A. (2012b) "What factors enable community leadership of renewable energy projects? Lessons from a woodfuel heating initiative," Local Economy: The Journal of the Local Economy Policy Unit. Thousand Oaks: SAGE Publishing, 27(2), pp. 209-22. DOI: 10.1177/0269094211429657.

Ruggiero, S., Martiskainen, M. and Onkila, T. (2018). "Understanding the scaling-up of community energy niches through strategic niche management theory: Insights from Finland," Journal of Cleaner Production. Amsterdam: Elsevier, 170, pp. 581-90. DOI: 10.1016/j.jclepro.2017.09.144.

Salm, S., Hille, S. L. and Wüstenhagen, R. (2016) "What are retail investors' risk-return preferences towards renewable energy projects? A choice experiment in Germany," Energy Policy. Amsterdam: Elsevier, 97, pp. 310-20. DOI: 10.1016/j.enpol.2016.07.042.

Scherrer, A., Plötz, P. and Van Laerhoven, F. (2020) "Power from above? Assessing actor related barriers to the implementation of trolley truck technology in Germany," Environmental Innovation and Societal Transitions. Amsterdam: Elsevier, 34, pp. 221-36. DOI: 10.1016/j.eist.2020.01.005.

Schot, J., Kanger, L. and Verbong, G. (2016) "The roles of users in shaping transitions to new energy systems," Nature Energy. London: Nature Research, 1 pp. 1-7. DOI: 10.1038/nenergy.2016.54.

Seyfang, G., Park, J. J. and Smith, A. (2013) "A thousand flowers blooming? An examination of community energy in the UK," Energy Policy. Amsterdam: Elsevier, 61, pp. 977-89. DOI: 10.1016/j.enpol.2013.06.030.

Smith, A. (2016) "Alternative technology niches and sustainable development: 12 years on," Innovation: Management, Policy and Practice. Abingdon: Routledge, 18(4), pp. 485-8. DOI: 10.1080/14479338.2016.1241153. 
Smith, A., Hargreaves, T., Hielscher, S., Martiskainen, M. and Seyfang, G. (2015) "Making the most of community energies: Three perspectives on grassroots innovation," Environment and Planning A: Economy and Space. Thousand Oaks: SAGE Publishing, 48(2), pp. 407-32. DOI: 10.1177/0308518X15597908.

Smith, A., Voß, J. P. and Grin, J. (2010) "Innovation studies and sustainability transitions: The allure of the multi-level perspective and its challenges," Research Policy, Amsterdam: Elsevier, 39(4), pp. 435-48. DOI: 10.1016/j.respol.2010.01.023.

Sorrell, S. (2007) "Improving the evidence base for energy policy: The role of systematic reviews," Energy Policy, Amsterdam: Elsevier, 35(3), pp. 1858-71. DOI: 10.1016/j. enpol.2006.06.008.

Süsser, D., Döring, M. and Ratter, B. M. W. (2017) "Harvesting energy: Place and local entrepreneurship in community-based renewable energy transition," Energy Policy. Amsterdam: Elsevier, 101, pp. 332-41. DOI: 10.1016/j.enpol.2016.10.018.

Tews, K. (2018) "The crash of a policy pilot to legally define community energy. Evidence from the German auction scheme," Sustainability. Basel: MDPI, 10(10), 3397. DOI: 10.3390/su10103397.

Torabi Moghadam, S., Di Nicoli, M. V., Manzo, S. and Lombardi, P. (2020) "Mainstreaming energy communities in the transition to a low-carbon future: A methodological approach,” Energies. Basel: MDPI AG, 13(7), p. 1597. DOI: 10.3390/en13071597.

trend:research (2017) Eigentümerstruktur: Erneuerbare Energien - Entwicklung der Akteursvielfalt, Rolle der Energieversorger, Ausblick bis 2020. 20-01174. Bremen, DE. Available at: https://www.trendresearch.de/studie.php?s=672.

Upham, P., Oltra, C. and Boso, À. (2015) "Towards a cross-paradigmatic framework of the social acceptance of energy systems," Energy Research and Social Science. Amsterdam: Elsevier, 8, pp. 100-112. DOI: 10.1016/j.erss.2015.05.003.

Walker, G. (2008) "What are the barriers and incentives for community-owned means of energy production and use?," Energy Policy. Amsterdam: Elsevier, 36(12), pp. 4401-5. DOI: $10.1016 /$ j.enpol.2008.09.032.

Walker, G. (2011) "The role for "community" in carbon governance," Wiley Interdisciplinary Reviews: Climate Change. Hoboken: Wiley-Blackwell, 2(5), pp. 777-82. DOI: 10.1002/ wcc. 137.

Walker, G. and Cass, N. (2007) "Carbon reduction, "the public" and renewable energy: Engaging with socio-technical configurations," Area. Hoboken: John Wiley \& Sons, 39(4), pp. 458-69. DOI: 10.1111/j.1475-4762.2007.00772.x.

Walker, G. and Devine-Wright, P. (2008) "Community renewable energy: What should it mean?," Energy Policy. Amsterdam: Elsevier, 36(2), pp. 497-500. DOI: 10.1016/j. enpol.2007.10.019.

Wierling, A., Schwanitz, V. J., Zeiß, J. P., Bout, C., Candelise, C., Gilcrease, W. and Gregg, J. S. (2018) "Statistical evidence on the role of energy cooperatives for the energy transition in European countries," Sustainability. Basel: MDPI, 10(9), p. 3339. DOI: $10.3390 /$ su10093339.

WindEurope (2019) Collapse in Wind Energy Growth Jeopardises German and EU Renewables Targets. Available at: https://windeurope.org/newsroom/press-releases/collapse-in -wind-energy-growth-jeopardises-german-and-eu-renewables-targets/.

Wolsink, M. (2018) "Social acceptance revisited: Gaps, questionable trends, and an auspicious perspective," Energy Research and Social Science. Amsterdam: Elsevier, 46, pp. 287-95. DOI: 10.1016/j.erss.2018.07.034.

Wüstenhagen, R., Wolsink, M. and Bürer, M. J. (2007) "Social acceptance of renewable energy innovation: An introduction to the concept," Energy Policy. Amsterdam: Elsevier, 35(5), pp. 2683-91. DOI: 10.1016/J.ENPOL.2006.12.001. 
Yildiz, Ö. (2014) "Financing renewable energy infrastructures via financial citizen participation - The case of Germany," Renewable Energy. Oxford: Pergamon Press, 68, pp. 677-85. DOI: 10.1016/j.renene.2014.02.038.

Yildiz, Ö., Rommel, J., Debor, S., Holstenkamp, L., Mey, F., Müller, J. R., Radtke, J. and Rognli, J. (2015) "Renewable energy cooperatives as gatekeepers or facilitators? Recent developments in Germany and a multidisciplinary research agenda," Energy Research Eु Social Science. Amsterdam: Elsevier, 6, pp. 59-73. DOI: 10.1016/j.erss.2014.12.001.

Yildiz, Ö. and Sagebiel, J. (2019) "Consumer (Co-)ownership and behaviour: Economic experiments as a tool for analysis," in Lowitzsch, J. (ed.), Energy Transition: Financing Consumer Co-Ownership in Renewables. Cham: Springer International Publishing, pp. 99-112. DOI: 10.1007/978-3-319-93518-8_5. 